\title{
Data management in substance use disorder treatment research: Implications from data harmonization of National Institute on Drug Abuse-funded randomized controlled trials
}

\author{
Ryoko Susukida, $\mathrm{PhD}^{1}$ \\ Masoumeh Aminesmaeili, MD, $\mathrm{MPH}^{1,2}$ \\ Ramin Mojtabai, MD, PhD, $\mathrm{MPH}^{1,3}$
}

${ }^{1}$ Department of Mental Health, Johns Hopkins Bloomberg School of Public Health, 624 N.

Broadway, Baltimore, MD, 21205, USA

${ }^{2}$ Iranian National Center for Addiction Studies (INCAS), Tehran University of Medical Sciences, No. 486, South Karegar Ave., Tehran, Iran

${ }^{3}$ Department of Psychiatry and Behavioral Sciences, Johns Hopkins University School of Medicine, 600 N. Wolfe St. Baltimore, MD 21287

Corresponding author:

Ryoko Susukida

624 N. Broadway Room 808, Baltimore, MD, 21205, USA

Telephone: $410-502-9344$

Fax: 410-614-7469

Email: rsusuki1@jhu.edu

Running title: Data management in SUD research

Word count: 2,868

Funding: This project was supported by a research award from Arnold Ventures. The content is solely the responsibility of the authors and does not necessarily represent the official views of Arnold Ventures. 
medRxiv preprint doi: https://doi.org/10.1101/2020.04.28.20081935; this version posted May 3, 2020. The copyright holder for this preprint (which was not certified by peer review) is the author/funder, who has granted medRxiv a license to display the preprint in perpetuity.

All rights reserved. No reuse allowed without permission.

\section{Abstract}

Background: Secondary analysis of data from completed randomized controlled trials (RCTs) is a critical and efficient way to maximize the potential benefit from past research. De-identified primary data from completed RCTs have been increasingly available in recent years; however, the lack of standardized data products is a major barrier to further use of these valuable data. Pre-statistical harmonization of data structure, variables and codebooks across RCTs would facilitate secondary data analysis including meta-analysis and comparative effectiveness studies. We describe a data harmonization initiative to harmonize de-identified primary data from substance use disorder (SUD) treatment RCTs funded by the National Institute on Drug Abuse (NIDA) available on the NIDA Data Share website.

Methods: Harmonized datasets with standardized data structures, variable names, labels, and definitions and harmonized codebooks were developed for 36 completed RCTs. Common data domains were identified to bundle data files from individual RCTs according to relevant subject areas. Variables within the same instrument were harmonized if at least two RCTs used the same instrument. The structures of the harmonized data were determined based on the feedback from clinical trialists and SUD research experts.

Results: We have created a harmonized database of variables across 36 RCTs with a build-in label, and a brief definition for each variable. Data files from the RCTs have been consistently categorized into eight domains (enrollment, demographics, adherence, adverse events, physical health measures, mental-behavioral-cognitive health measures, self-reported substance use measures, and biologic substance use measures). Harmonized codebooks and instrument/variable concordance tables have also been developed to help identify instruments and variables of interest more easily.

Conclusions: The harmonized data of RCTs of SUD treatments can potentially promote future secondary data analysis of completed RCTs, allowing combining data from multiple RCTs and provide guidance for future RCTs in SUD treatment research. 
medRxiv preprint doi: https://doi.org/10.1101/2020.04.28.20081935; this version posted May 3, 2020. The copyright holder for this preprint (which was not certified by peer review) is the author/funder, who has granted medRxiv a license to display the preprint in perpetuity. All rights reserved. No reuse allowed without permission.

Keywords: Randomized controlled trials; secondary data analysis; substance abuse treatment; data harmonization 
medRxiv preprint doi: https://doi.org/10.1101/2020.04.28.20081935; this version posted May 3, 2020. The copyright holder for this preprint (which was not certified by peer review) is the author/funder, who has granted medRxiv a license to display the preprint in perpetuity.

All rights reserved. No reuse allowed without permission.

\section{Background}

Data sharing of de-identified primary data from randomized controlled trials (RCTs) has been increasingly promoted by the National Institutes of Health (NIH) (1). Secondary analysis of data from the completed RCTs is a critical and efficient way to maximize the potential benefit from past research. Designing RCTs for new treatments should ideally reflect the lessons and implications from the past RCTs. Greater availability of data would also allow investigators not involved in the primary research to confirm the findings of the original investigators, explore relationships of theoretic and clinical interest that were not examined by primary investigators, and conduct more powerful tests of hypotheses through combining multiple datasets.

Furthermore, the pooled data would provide cost-effective resources for comparative efficacy studies by allowing comparisons across multiple active treatment arms. These include, for example, analyses of treatment response in under-represented population subgroups and exploration of treatment response heterogeneity in patients with risk profiles. Such data can promote new directions for research by identifying population groups who would most benefit from interventions and hence contribute to ultimately improving clinical practices.

De-identified primary data from completed RCTs have been increasingly available in recent years in various biomedical research fields. There are several organizations making critical efforts to provide researchers with user-friendly and/or harmonized RCT data for further scientific research. Some of the data repositories include the Inter-university Consortium of Political and Social Research (ICPSR), the Yale University of Open Data Access (YODA), the NIMH data archive (2), ClinicalStudyDataRequest.com (CSDR) (3), and Vivli Center for Global Clinical Research Data (4). In the field of substance use disorder (SUD) treatment, the National Institute for Drug Abuse (NIDA) has made data from the completed RCTs publicly available through the NIDA Data Share website (5) to encourage secondary analysis of completed RCTs in substance use disorder (SUD) treatment research. The NIDA Data Share website includes data from completed RCTs which were conducted under 1) the National Drug Abuse Treatment 
medRxiv preprint doi: https://doi.org/10.1101/2020.04.28.20081935; this version posted May 3, 2020. The copyright holder for this preprint (which was not certified by peer review) is the author/funder, who has granted medRxiv a license to display the preprint in perpetuity.

All rights reserved. No reuse allowed without permission.

Clinical Trials Network (CTN), where patients were recruited from a broad range of communitybased SUD treatment settings, and 2) the Division of Therapeutics and Medical Consequences (DTMC) program, where patients were recruited through advertisement in various academic institutions, federal therapeutic development institutions, and the pharmaceutical and biotechnology sectors to test effectiveness of innovative SUD pharmacotherapies. Deposited data from NIDA-funded RCTs are an extremely valuable resource for advancing the standard of evidence-based care for SUDs in the United States, where a high prevalence of SUDs is one of the most significant public health issues and there is a critical need for more efficacious interventions for these conditions.

As more data from RCTs have become available, there is also a growing number of secondary analyses of RCT data. However, only a limited number of secondary analyses of RCT data have been conducted and published by entirely independent investigators who were not part of the primary RCT investigative team (6). There have been increasing calls for secondary analyses of RCT data by independent investigators to ensure research reproducibility. The NIDA Data Share website has been providing a valuable resource for secondary analyses of RCT data within the SUD research community.

The NIDA CTN Dissemination Library store all publications that involved analyses of the CTN RCT data. At the time of this writing, there were a total of 636 of published documents including peer-reviewed journals, posters and newsletters, most of which were secondary analyses of data based on NIDA CTN RCTs (7). However, only 34 (5.3\%) of these documents were published by entirely independent investigators, perhaps partly due to difficulty to use the RCT data from the NIDA Data Share website. This highlights the importance of maximizing the usability of the data from NIDA-funded RCTs to enable independent investigators to analyze data easily. While the primary data from completed SUD RCTs are currently downloadable from the NIDA Data Share website, the lack of standardized data products with consistent variable 
medRxiv preprint doi: https://doi.org/10.1101/2020.04.28.20081935; this version posted May 3, 2020. The copyright holder for this preprint (which was not certified by peer review) is the author/funder, who has granted medRxiv a license to display the preprint in perpetuity.

All rights reserved. No reuse allowed without permission.

names, labels, and codebooks is a major barrier to further use of these valuable data. Due to these logistical data challenges, this valuable data resource is currently underutilized.

Harmonizing data structure, variables and codebooks across RCTs would facilitate secondary data analysis including meta-analysis and comparative effectiveness studies. The primary purpose of this paper is to describe a data harmonization initiative to harmonize deidentified primary data from NIDA-funded SUD treatment RCTs available on the NIDA Data Share website. We aimed to develop harmonized datasets of 36 NIDA-funded RCTs that were deposited on the NIDA Data share website by September 2018.

\section{Method}

\section{NIDA-funded RCTs}

There were 36 primary data publicly available from the NIDA Data Share website by September 2018, including one RCT follow-up study (CTN0030A3). We excluded open-label trials, feasibility trials, safety trials, non-randomized trials, and RCTs focusing on non-SUD outcomes from our data harmonization initiative. Table 1 presents the list of 36 RCTs included in this data harmonization initiative. There were 23 RCTs conducted under the CTN, 13 RCTs conducted under the DTMC program. By target substances, 16 RCTs targeted stimulants including cocaine and methamphetamine, 9 RCTs targeted opioids, 8 RCTs targeted any substances, and 3 RCTs targeted nicotine. By intervention types, 23 RCTs tested the effectiveness of pharmacological interventions while 13 RCTs tested the effectiveness of behavioral interventions. The sample size varied from 62 (CTN0052) to 1,285 (CTN0047).

\section{Development of harmonized data format}

A number of instruments were utilized in each completed RCT. Instruments included standardized tools in SUD research fields such as the Addiction Severity Index (ASI) and the 
medRxiv preprint doi: https://doi.org/10.1101/2020.04.28.20081935; this version posted May 3, 2020. The copyright holder for this preprint (which was not certified by peer review) is the author/funder, who has granted medRxiv a license to display the preprint in perpetuity.

All rights reserved. No reuse allowed without permission.

Clinical Opiate Withdrawal Scale (COWS). The datasets in the harmonized database were designed so that each data file contains only one instrument and that the number of data files corresponds to the number of instruments used in each RCT. Data files have been named in a consistent manner representing each RCT identifier and instrument name. Each harmonized data file has also been provided in both a comma-separated values (CSV) file and a Stata (version 14; Stata Corp, College Station, TX, USA) *.dta data file.

To help users identify the instrument of interest more easily, common data domains were identified to bundle each data file according to its relevant subject area. Furthermore, variables within the same instrument were harmonized if two or more RCTs used the same instrument. The structures of the harmonized data were determined based on the feedback from the advisory board member consisting of clinical trialists and SUD research experts.

\section{Codebooks and supplemental documentations}

For some RCTs, NIDA Data Share website provided some data along with codebooks that describe the definitions of each variable (e.g., CTN0037, CTN0044); whereas, for other studies only annotated questionnaires were provided as a guide to using the data (e.g., CTN0001, CTN0004). These data were used for identifying variables, developing uniform variable names and consistent variable and value labels. We also developed standardized codebooks for the harmonized data. The standardized codebooks were produced with the codebook command in Stata, version 14 (Stata Corp, College Station, TX, USA). Furthermore, we have developed several supplemental documents including 1) a user's guide which documents processing notes for harmonized RCT data, 2) an instrument concordance table, which allows users to identify which instruments are comparable across different RCTs, 3) a variable concordance table, which allows users to identify which variables in each instrument are comparable across different RCTs, and 4) an assessment schedule table which tabulates assessment schedule for main outcome instruments (e.g., ASI) in each study. 
medRxiv preprint doi: https://doi.org/10.1101/2020.04.28.20081935; this version posted May 3, 2020. The copyright holder for this preprint (which was not certified by peer review) is the author/funder, who has granted medRxiv a license to display the preprint in perpetuity.

All rights reserved. No reuse allowed without permission.

\section{Results}

Since the inception of this data harmonization initiative in September 2018, we have developed a beta version of the harmonized database of 36 NIDA-funded SUD RCTs and produced standardized codebooks as well as supplemental documentation including a user's guide, concordance tables (for instruments and variables), and assessment schedule table.

\section{Harmonized data structure}

Figure 1 presents the data structure of the harmonized data. Each RCT comes with a number of instruments, each of which has been stored in a separate data file. Instruments include not only standardized instruments such as ASI and COWS but also non-standardized instruments such as demographics form that varies in content across studies. The number of instruments ranged from 16 to 48 per RCT. Each instrument is provided in a separate data file and data files are named in a consistent manner. For example, the data file for ASI in CTN0001 is named "CTN0001_ASI." The list of abbreviated names for each instrument (e.g., ASI for Addiction Severity Index) is provided in one of the supplemental documents, the instrument concordance table, which is described below.

All the data files for each RCT have been consistently categorized into eight data domains:1) enrollment, containing information regarding eligibility criteria for RCT participation; 2) demographics, containing basic demographic information such as age, sex, and race/ethnicity; 3) adherence, containing information regarding the number of visits made and qualitative measures of adherence with treatments; 4) adverse events, containing information about medication and therapy related adverse events and often divided into severe and less than severe adverse events; 5) physical health measures, containing basic physical health information such as height, weight and blood pressure as well as information on medical history and prior/concomitant medications; 6) mental-behavioral-cognitive health measures, containing information regarding psychological well-being based on standardized tools such as Beck 
medRxiv preprint doi: https://doi.org/10.1101/2020.04.28.20081935; this version posted May 3, 2020. The copyright holder for this preprint (which was not certified by peer review) is the author/funder, who has granted medRxiv a license to display the preprint in perpetuity.

All rights reserved. No reuse allowed without permission.

Depression Inventory and 36-Item Short Form Survey; 7) self-reported substance use measures, containing information based on self-administered tools such as ASI and Time Line Follow Back Scale; and 8) biologic substance use measures, containing information based on objective measures of substance use such as urine toxicology and alcohol breathalyzer.

Data presentation of variables in each data file has been made consistent across different RCTs with a build-in label and brief definition for each variable. The data files were so created that each data file starts with a set of seven variables (Figure 2) that is consistent across all datafiles. These variables allow users to combine multiple datasets from the RCT and also allow them to conduct basic analyses using each datafile separately. The first variable, "studyid", represents the NIDA study identification code (e.g. CTN0001). The second variable, "usubjid", represents the de-identified subject identification code. The third variable, "arm", represents whether a patient was randomly assigned to active treatment or control arms. Names for treatment arms were taken directly from original data files. We created variables "arm1" (treatment arm for phase 1) and "arm2" (treatment arm for phase 2) for study NIDACTN0030/0030A, which was a two-step trial. Variable "arm" for those who were not randomized but had baseline assessments was coded either as "not randomized" or left missing. The fourth variable, "assessdays", represents days since randomization (e.g., $-3=3$ days before randomization) for each assessment. The fourth variable, "visno" represents RCT-specific assessment visit number (e.g., WEEK4V1). The fifth variable, "phase", represents the phase of the study, which was derived based on "visno" to allow users to distinguish whether assessments were recorded before the active treatment ("BASELINE"), during active treatment (“ACTIVE”), or after active treatment (“FOLLOWUP). Exceptionally for CTN0030/0030A, which was a two-step trial, we created two values for active phase, "ACTIVE1" (during phase 1 treatment) and "ACTIVE2" (during phase 2 treatment). The seventh variable, "measure", represents the name of the instruments stored in a data file (e.g., ADDICTION SEVERITY INDEX-LITE). Data files for most of the measures have been structured in a long (longitudinal) 
medRxiv preprint doi: https://doi.org/10.1101/2020.04.28.20081935; this version posted May 3, 2020. The copyright holder for this preprint (which was not certified by peer review) is the author/funder, who has granted medRxiv a license to display the preprint in perpetuity.

All rights reserved. No reuse allowed without permission.

format, where there are multiple assessments recorded vertically across different phases of the study. Because in many cases variables "assessdays", "visno", and "phase" were not all available for every assessment due to missing information in original data files, a variable "sequence" (integer starting from one) was created for some instruments, using available variables, which allows users to distinguish multiple assessments.

\section{Codebooks and supplemental documentations}

Harmonized codebooks were produced using information from various documents for each CTN study available from the NIDA Data Share Website, including annotated questionnaires, protocols and spreadsheets of data dictionaries. Variable name with its brief description, variable type (string/numeric), the number of missing values, and frequency tabulation have been included for all variables. For string variables (e.g., patient id), the number of unique values has been also presented. For numeric continuous variables (e.g., quantitative measures from a urine sample), mean, standard deviation, and frequency tabulation (percentiles) have been presented. For numeric categorical variables (e.g., qualitative measures from a urine sample), range of values and variable labels for associated numeric values have been presented.

Several supplemental documents were also created. These included first, a user's guide, which briefly describes how the harmonized data files were constructed, and how instruments and variables of interest can be found for secondary data analysis. The user's guide also describes how data files can be merged with each other by providing several examples. Second, we have developed an instrument concordance table that helps users to identify which instruments/measures are included in each domain for each RCT. This document is especially useful since instruments/measures under each domain varied for every RCT (Figure 3). The instrument concordance table allows users to easily identify comparable instruments/measures across different RCTs. Third, we have created a variable concordance table since some items were omitted from instruments/measures in some RCTs (e.g., quantitative measures for urine 
medRxiv preprint doi: https://doi.org/10.1101/2020.04.28.20081935; this version posted May 3, 2020. The copyright holder for this preprint (which was not certified by peer review) is the author/funder, who has granted medRxiv a license to display the preprint in perpetuity.

All rights reserved. No reuse allowed without permission.

toxicology tests were only available for a subset of $36 \mathrm{RCTs})$. The variable concordance table presents the item-level concordance within a particular instrument. Fourth, we have created an assessment schedule table showing the timing and frequencies of assessment for major SUD outcome measures such as urine toxicology tests and ASI for each RCT (Figure 4).

\section{Examples of secondary data analyses}

Table 2 presents basic descriptive statistics of 36 RCTs. Harmonized data allow researchers to easily pool data multiple RCTs and conduct comparative studies across RCTs. Secondary analyses leveraging the harmonized data have been published by our investigative team, a group of researchers who have not involved in primary data collection of the NIDA-funded RCTs (8-14). First, a series of studies by Susukida et al. (8-12) examined the generalizability of the findings from SUD RCTs to the target populations. These studies used harmonized data of NIDA-funded RCTs described above and compared the characteristics of individuals participating in SUD RCTs with individuals receiving treatment in usual care settings. The main findings of these studies were that individuals recruited into SUD RCTs appear to differ in significant was from individuals receiving treatment in usual care settings. Specifically, RCT participants had more years of education and a greater likelihood of full-time work compared with people receiving care in usual care settings. In a further step, statistical weighting was used to re-compute the effects from these SUD RCTs such that the RCT participants had characteristics that resembled those of patients in the target populations. Such re-weighting of the samples changed the treatment effects in a number of the RCTs. Most commonly, the positive effects of trials became statistically non-significant after re-weighting the RCT sample to match the target population.

Second, we conducted a study assessing the validity of the psychiatric problems subscale of the ASI (ASI-psych) (13), a detailed measure commonly used in SUD treatment research, to detect psychiatric comorbidity using pooled harmonized data from 11 NIDA-funded RCTs involving 1,660 participants. Our results demonstrated moderate accuracy of the ASI- 
medRxiv preprint doi: https://doi.org/10.1101/2020.04.28.20081935; this version posted May 3, 2020. The copyright holder for this preprint (which was not certified by peer review) is the author/funder, who has granted medRxiv a license to display the preprint in perpetuity.

All rights reserved. No reuse allowed without permission.

psych in detecting the presence of any serious mental disorder against the gold standard of diagnosis based on structured or semi-structured interviews. The results support the utility of ASI-psych in screening psychiatric comorbidity among patients receiving substance use disorder treatments in RCT settings.

Furthermore, in collaboration with biostatistician, we have conducted a study to examine precision and power gains associated with adjustment for baseline variables in stratified RCTs, using the harmonized data of three stratified NIDA RCTs (14). The results demonstrated that the variance of the treatment estimates reduced up to $35 \%$ by adjusting for baseline variables, indicating that researchers planning to perform adjustment for strata and additional baseline variables could achieve the same precision with approximately $35 \%$ fewer participants.

\section{Conclusions}

As the country struggles to tackle the growing problem of SUDs and particularly, the recent opioid epidemic, there is a pressing need for reproducible and generalizable studies to examine various interventions. The NIDA Data Share website includes data from numerous studies involving thousands of patients treated for various SUDs. Secondary analyses of these data can provide useful information by addressing new questions about treatment of SUDs and formulating new hypotheses. Our data harmonization initiative has made these data more accessible and user-friendly to a wide circle of researchers, which would encourage various secondary data analyses and help advance the standard of research and potentially ultimately, treatment, of various SUDs. The societal benefits from the deliverables from this data harmonization initiative are expected to be quite large and timely in the face of critical public health concerns in our nation. Future directions and next steps include the effective dissemination of the harmonized data to encourage secondary data analyses in the broader scientific community.

\section{Acknowledgments}


medRxiv preprint doi: https://doi.org/10.1101/2020.04.28.20081935; this version posted May 3, 2020. The copyright holder for this preprint (which was not certified by peer review) is the author/funder, who has granted medRxiv a license to display the preprint in perpetuity. All rights reserved. No reuse allowed without permission.

We thank the advisory board members (Dr. Kathleen T. Brady; Dr. Cynthia Campbell; Dr. Walter Ling; Dr. John Rotrosen; Dr. Betty Tai; Dr. Xiaoming Wang; Dr. Li-Tzy Wu) for their valuable feedback on this data harmonization initiative.

\section{Declarations of competing interest}

Dr. Susukida and Dr. Aminesmaeili have nothing to disclose. Dr. Mojtabai report grants from the National Institute on Drug Abuse and National Institute of Mental Health during the conduct of the study. Dr. Mojtabai has received research funding and consulting fees from Bristol-Myers Squibb and Lundbeck Pharmaceuticals. 
medRxiv preprint doi: https://doi.org/10.1101/2020.04.28.20081935; this version posted May 3, 2020. The copyright holder for this preprint (which was not certified by peer review) is the author/funder, who has granted medRxiv a license to display the preprint in perpetuity.

All rights reserved. No reuse allowed without permission.

\section{References}

1. National Institutes of Health. NIH Data Sharing Policy and Implementation Guidance 2003 [Available from:

https://grants.nih.gov/grants/policy/data sharing/data sharing guidance.htm\#goals.

$2 . \quad$ NIMH. The National Institute of Mental Health Data Archive (NDA) [02/26/2020].

Available from: https://nda.nih.gov/about/contact-us.html.

3. CSDR. Clinical Study Data Request [Available from:

https://www.clinicalstudydatarequest.com/.

4. Vivli. Center for Global Clinical Research Data [Available from: https://vivli.org/.

5. Pan JJ, Nahm M, Wakim P, Cushing C, Poole L, Tai B, et al. A centralized informatics infrastructure for the National Institute on Drug Abuse Clinical Trials Network. Clin Trials. 2009;6(1):67-75.

6. Ebrahim S, Sohani ZN, Montoya L, Agarwal A, Thorlund K, Mills EJ, et al. Reanalyses of randomized clinical trial data. Jama. 2014;312(10):1024-32.

7. The Clinical Trail Netwrok (CTN) dissemination library The University of Washington Alcohol and Drug Abuse InstituteThe CTN Dissemination Library, [Available from:

http://ctndisseminationlibrary.org/.

8. $\quad$ Susukida R, Crum RM, Stuart EA, Ebnesajjad C, Mojtabai R. Assessing sample representativeness in randomized controlled trials: application to the National Institute of Drug Abuse Clinical Trials Network. Addiction. 2016;111(7):1226-34.

9. Susukida R, Crum RM, Ebnesajjad C, Stuart EA, Mojtabai R. Generalizability of findings from randomized controlled trials: application to the National Institute of Drug Abuse Clinical Trials Network. Addiction. 2017;112(7):1210-9.

10. Susukida R, Crum RM, Hong $H$, Stuart EA, Mojtabai R. Comparing pharmacological treatments for cocaine dependence: Incorporation of methods for enhancing generalizability in meta-analytic studies. Int J Methods Psychiatr Res. 2018;27(4):e1609.

11. Susukida R, Crum RM, Stuart EA, Mojtabai R. Generalizability of the findings from a randomized controlled trial of a web-based substance use disorder intervention. Am J Addict. 2018;27(3):231-7.

12. Ackerman B, Schmid I, Rudolph KE, Seamans MJ, Susukida R, Mojtabai R, et al. Implementing statistical methods for generalizing randomized trial findings to a target population. Addict Behav. 2019;94:124-32.

13. Susukida R, Mojtabai R, Amin-Esmaeili M. Validation of Addiction Severity Index (ASI) for Assessment of Psychiatric Comorbidity in National Institute of Drug Abuse Clinical Trials Network. Journal of Dual Diagnosis. 2020;Under-review.

14. Wang B, Susukida R, Mojtabai R, Amin-Esmaeili M, Rosenblum M. Model-Robust Inference for Clinical Trials that Improve Precision by Stratified Randomization and Adjustment for Additional Baseline Variables. [Methodology (stat.ME)]. In press 2019. 
medRxiv preprint doi: https://doi.org/10.1101/2020.04.28.20081935; this version posted May 3, 2020. The copyright holder for this preprint (which was not certified by peer review) is the author/funder, who has granted medRxiv a license to display the preprint in perpetuity. All rights reserved. No reuse allowed without permission.

Figure 1. Structure of harmonized data

DOMAINS

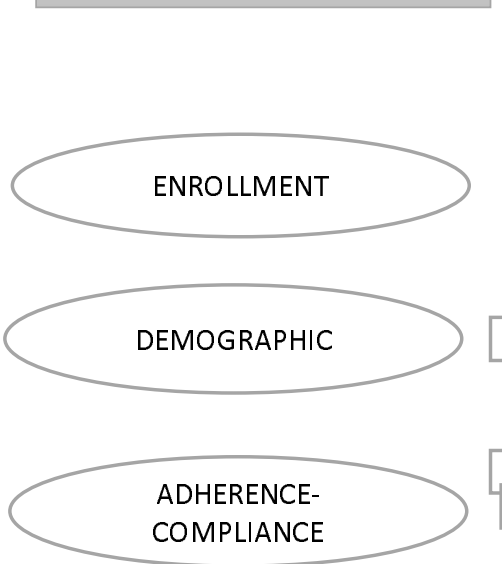

INSTRUMENTS

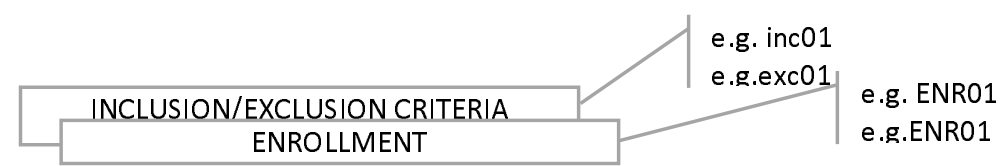

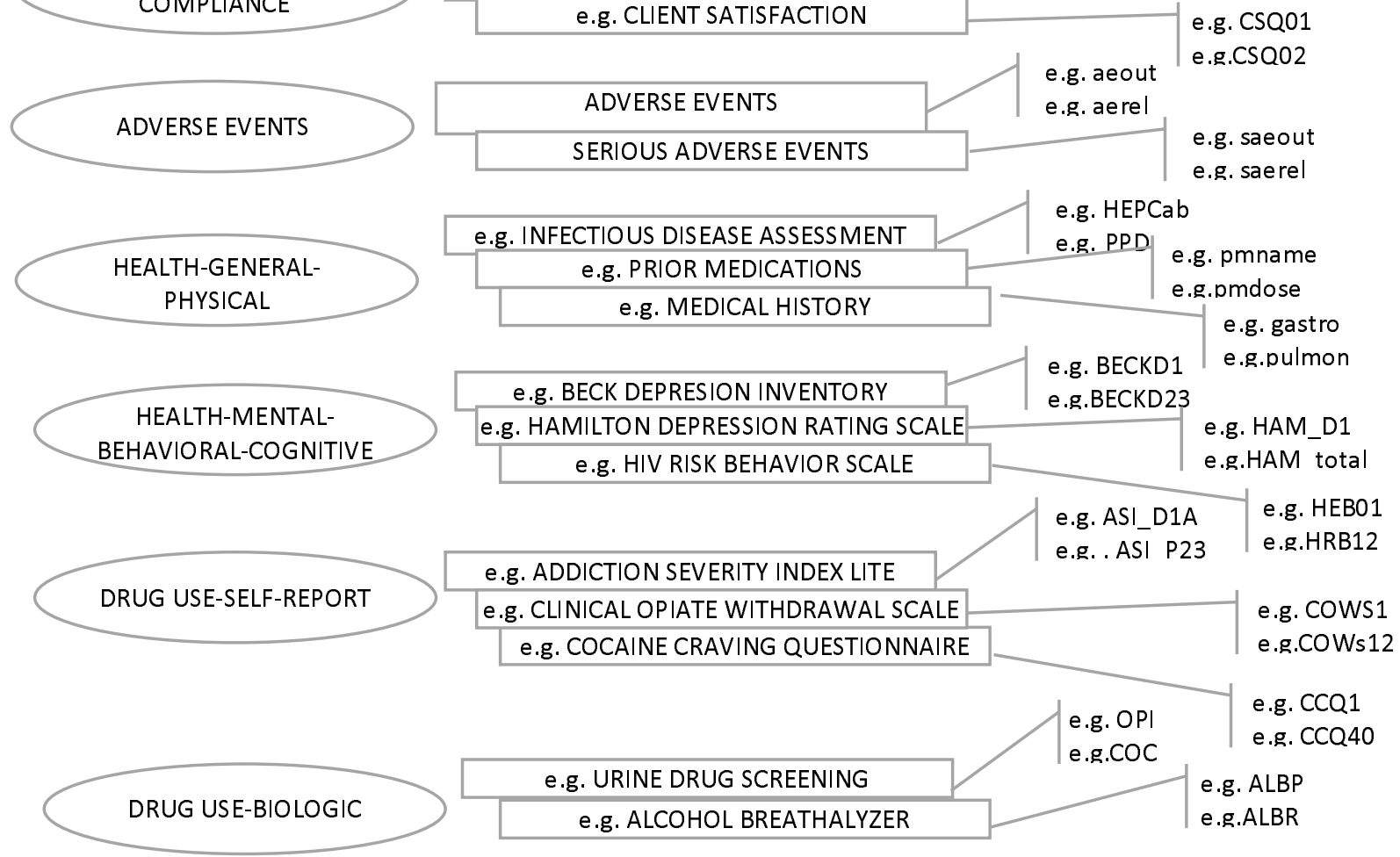


medRxiv preprint doi: https://doi.org/10.1101/2020.04.28.20081935; this version posted May 3, 2020. The copyright holder for this preprint (which was not certified by peer review) is the author/funder, who has granted medRxiv a license to display the preprint in perpetuity. All rights reserved. No reuse allowed without permission.

Figure 2. Harmonized data presentation of variables in each data file (e.g. CTO0005, Urine Drug Screening data file)

\begin{tabular}{|c|c|c|c|c|c|c|c|c|c|c|c|c|c|c|c|c|c|c|}
\hline \multicolumn{3}{|c|}{$\begin{array}{l}\text { Study ID } \\
\text { "studyid" }\end{array}$} & \multicolumn{2}{|c|}{$\begin{array}{l}\text { Subject ID } \\
\text { "usubjid" }\end{array}$} & \multicolumn{2}{|c|}{$\begin{array}{c}\text { Treatment } \\
\text { arm } \\
\text { :arm" }\end{array}$} & \multicolumn{2}{|c|}{$\begin{array}{l}\text { Days since } \\
\text { randomization } \\
\text { "assessdays" }\end{array}$} & \multicolumn{3}{|c|}{$\begin{array}{c}\text { Study specific } \\
\text { visit ID } \\
\text { "visno" }\end{array}$} & \multicolumn{3}{|c|}{$\begin{array}{l}\text { Study phase } \\
\text { "phase" }\end{array}$} & \multicolumn{2}{|c|}{\begin{tabular}{|c|} 
Measures/ \\
instruments \\
"measure"
\end{tabular}} & & \\
\hline & studyid & usubjid & & arm & assessdays & visno & phase & & measure & & & D1A & D1B & D1C & D2A & D2B & D2C & D3A \\
\hline 1 & сто0005 & $05 \_4891$ & $4.0=$ & mg ondansetron & -3 & SCRNBASE & BASELINE & ADDICTION & SEVERITY & INDEX & LITE & 28 & 20 & . & 0 & 5 & . & 0 \\
\hline 2 & сто0005 & 05_4891 & 4.0 & mg ondansetron & 28 & WEEK $4 \mathrm{~V} 1$ & ACTIVE & ADDICTION & SEVERITY & INDEX & LITE & 18 & 20 & . & 0 & 1 & . & 0 \\
\hline 3 & сто0005 & 05_4891 & $4.0=$ & $\mathrm{mg}$ ondansetron & 60 & WEEK8V3 & ACTIVE & ADDICTION & SEVERITY & INDEX & LITE & 12 & 20 & . & 0 & 1 & . & 0 \\
\hline 4 & cто0005 & $05 \_8342$ & 4.0 & mg ondansetron & -2 & SCRNBASE & BASELINE & ADDICTION & SEVERITY & INDEX & LITE & 20 & 25 & . & 0 & 0 & . & 0 \\
\hline 5 & сто0005 & $05 \_8342$ & 4.0, & mg Ondansetron & 61 & WEEK8V 3 & ACTIVE & ADDICTION & SEVERITY & INDEX & LITE & 13 & 23 & . & 0 & 0 & . & 0 \\
\hline 6 & сто0005 & $05 \_12200$ & & Placebo & -14 & SCRNBASE & BASELINE & ADDICTION & SEVERITY & INDEX & LITE & 10 & 16 & . & 10 & 5 & . & 0 \\
\hline 7 & cт00005 & $05 \_12200$ & & Placebo & 31 & WEEK $4 \mathrm{~V} 1$ & ACTIVE & ADDICTION & SEVERITY & INDEX & LITE & 6 & 15 & . & 3 & 0 & . & 0 \\
\hline 8 & сто0005 & $05 \_36247$ & & Placebo & -10 & SCRNBASE & BASELINE & ADDICTION & SEVERITY & INDEX & LITE & 8 & 8 & . & 7 & 6 & . & 0 \\
\hline 9 & сто0005 & $05{ }^{3} 36247$ & & Placebo & 37 & WEEK 4V1 & ACTIVE: & ADDICTION & SEVERITY & INDEX & LITE & 10 & 6 & . & 6 & 4 & . & 0 \\
\hline 10 & сто0005 & 05_56602 & $0.25=$ & $\mathrm{mg}$ ondansetron & -12 & SCRNBASE & BASELINE & ADDICTION & SEVERITY & INDEX & LITE & 2 & 10 & . & 0 & 10 & . & 0 \\
\hline 11 & сто0005 & 05_100607 & & Placebo & -8 & SCRNBASE & BASELINE & ADDICTION & SEVERITY & INDEX & LITE & 14 & 23 & . & 7 & 1 & . & 0 \\
\hline 12 & cto0005 & 05_100607 & & Placebo & 26 & WEEK 4V 1 & ACTIVE & ADDICTION & SEVERITY & INDEX & LITE & 5 & 23 & . & 0 & 6 & . & 0 \\
\hline 13 & сто0005 & 05_100607 & & Placebo & 62 & WEEK8V 3 & ACTIVE & ADDICTION & SEVERITY & INDEX & LITE & 2 & 23 & . & 0 & 6 & . & 0 \\
\hline 14 & сто0005 & 05_105642 & & Not randomized & . & SCRNBASE & BASELINE & ADDICTION & SEVERITY & INDEX & LITE & 4 & 6 & . & 0 & 6 & . & 0 \\
\hline 15 & cто0005 & 05_107072 & $0.25=$ & mg ondansetron & -13 & SCRNBASE & BASELINE & ADDICTION & SEVERITY & INDEX & LITE & 10 & 30 & . & 0 & 20 & . & 0 \\
\hline 16 & сто0005 & 05_107072 & $0.25=$ & $\mathrm{mg}$ ondansetron & 30 & WEEK $4 \mathrm{~V} 1$ & ACTIVE & ADDICTION & SEVERITY & INDEX & LITE & 10 & 30 & . & 6 & 28 & . & 0 \\
\hline 17 & сто0005 & 05_130936 & $1.0=$ & mg ondansetron & -8 & SCRNBASE & BASELINE & ADDICTION & SEVERITY & INDEX & LITE & 12 & 23 & . & 1 & 10 & . & 0 \\
\hline 18 & cто0005 & 05_130936 & $1.0=$ & mg ondansetron & 25 & WEEK4V1 & ACTIVE & ADDICTION & SEVERITY & INDEX & LITE & 20 & 25 & . & 1 & 10 & . & 0 \\
\hline 19 & сто0005 & 05_130936 & 1.0 & mg ondansetron & 46 & WEEK8V 3 & ACTIVE & ADDICTION & SEVERITY & INDEX & LITE & 15 & 25 & . & 1 & 10 & . & 0 \\
\hline 20 & cTo0005 & 05_133137 & $0.25=$ & mg ondansetron & -11 & SCRNBASE & BASELINE & ADDICTION & SEVERITY & INDEX & LITE & 0 & 16 & . & 0 & 4 & . & 1 \\
\hline 21 & CTO0005 & 05_133137 & 0.25 & mg ondansetron & 28 & WEEK $4 \mathrm{~V} 1$ & ACTIVE & ADDICTION & SEVERITY & INDEX & LITE & 1 & 15 & . & 1 & 15 & . & 0 \\
\hline 22 & cт00005 & 05_135020 & 0.25 & mg ondansetron & -13 & SCRNBASE & BASELINE & ADDICTION & SEVERITY & INDEX & LITE & 20 & 26 & . & 20 & 26 & . & 0 \\
\hline 23 & сто0005 & 05_146359 & & Not randomized & . & SCRNBASE & BASELINE & ADDICTION & SEVERITY & INDEX & LITE & 3 & 30 & . & 0 & 0 & . & 0 \\
\hline 24 & сто0005 & 05_151710 & $0.25=$ & mg ondansetron & -8 & SCRNBASE & BASELINE & ADDICTION & SEVERITY & INDEX & LITE & 0 & 0 & . & 0 & 0 & . & 0 \\
\hline 25 & cто0005 & 05_151710 & 0.25 & mg ondansetron & 28 & WEEK $4 \mathrm{~V} 1$ & ACTIVE & ADDICTION & SEVERITY & INDEX & LITE & 0 & 0 & . & 0 & 0 & . & 0 \\
\hline 26 & Cт00005 & 05_171483 & & Not randomized & . & SCRNBASE & BASELINE & ADDICTION & SEVERITY & INDEX & LITE & 20 & 28 & . & 15 & 12 & . & 0 \\
\hline 27 & CT00005 & 05_176622 & $1.0=$ & mg ondansetron & -8 & SCRNBASE & BASELINE & ADDICTION & SEVERITY & INDEX & LITE & 14 & 9 & . & 14 & 9 & . & 0 \\
\hline 28 & cт00005 & 05_176622 & $1.0=$ & mg ondansetron & 50 & WEEK8V3 & ACTIVE & ADDICTION & SEVERITY & INDEX & LITE & 12 & 9 & . & 9 & 9 & . & 0 \\
\hline 29 & сто000 5 & 05_182325 & & Placebo & -4 & SCRNBASE & BASELINE & ADDICTION & SEVERITY & INDEX & LITE & 6 & 20 & . & 6 & 20 & . & 0 \\
\hline 30 & сто0005 & 05_189928 & 0.25 & mg ondansetron & -7 & SCRNBASE & BASELINE & ADDICTION & SEVERITY & INDEX & LITE & 6 & 2 & . & 2 & 2 & . & 0 \\
\hline 31 & cT00005 & 05_192852 & $4.0=$ & mg ondansetron & -9 & SCRNBASE & BASELINE & ADDICTION & SEVERITY & INDEX & LITE & 8 & 12 & . & 0 & 0 & . & 0 \\
\hline 32 & сто0005 & 05_192852 & $4.0=$ & mg ondansetron & 31 & WEEK4V1 & ACTIVE & ADDICTION & SEVERITY & INDEX & LITE & 8 & 15 & . & 0 & 0 & . & 0 \\
\hline 33 & сто0005 & 05_195100 & 0.25 & mg ondansetron & -12 & SCRNBASE & BASBLINE & ADDICTION & SEVERITY & INDEX & LITE & 0 & 15 & . & 0 & 0 & . & 0 \\
\hline 34 & сто0005 & 05_195100 & 0.25 & mg ondansetron & 38 & WEEK8V 3 & ACTIVE & ADDICTION & SEVERITY & INDEX & LITE & 2 & 0 & . & 0 & 0 & . & 0 \\
\hline & or & $n, \ldots+\cdots$ & & 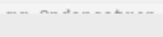 & $\cdots$ & & & & & & & .. & a & & - & n & & 个 \\
\hline
\end{tabular}


medRxiv preprint doi: https://doi.org/10.1101/2020.04.28.20081935; this version posted May 3, 2020. The copyright holder for this preprint (which was not certified by peer review) is the author/funder, who has granted medRxiv a license to display the preprint in perpetuity. All rights reserved. No reuse allowed without permission.

\section{Figure 3. Excerpt from instrument concordance table}

\begin{tabular}{|c|c|c|c|c|c|c|c|c|c|c|c|c|c|c|c|c|c|c|c|c|c|c|c|c|c|c|c|c|c|c|c|c|c|c|c|c|}
\hline domain & measure & shortname & 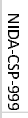 & 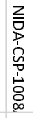 & 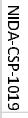 & 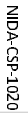 & 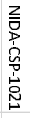 & 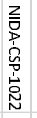 & 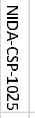 & 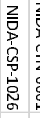 & 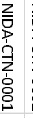 & 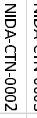 & 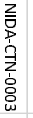 & 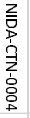 & & 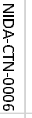 & 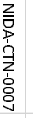 & 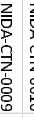 & & & & & & & & & & & & & & & & $\begin{array}{l}2 \\
0 \\
0 \\
0 \\
0 \\
0 \\
0\end{array}$ & 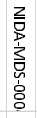 & 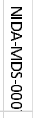 \\
\hline ADHERENCE/COMPLIANCE & CLIENT SATISFACTION QUESTIONNAIRE & csa & & & & & & & & & & $\mathrm{x}$ & $x$ & & $x$ & & & & $\mathrm{x}$ & $x$ & $\mathrm{x}$ & & & & & & $\mathrm{x}$ & & & & & & & & & \\
\hline ADHERENCE/COMPLIANCE & COMPLIANCE & COMP & & & & & & $x$ & $x>$ & $x$ & & & & & & & & $x$ & & & & & $x$ & & & & & $x$ & & & & & & $\mathrm{x}$ & & \\
\hline ADHERENCE/COMPLIANCE & DOSE ADMINISTRATION RECORD & DOSEA & $\mathrm{x}$ & & & $x$ & $x$ & & $x$ & $x \times$ & $x \times$ & $x \quad x$ & & & & & & $x$ & & & & & & $x$ & & & & & & & $x$ & & & & & \\
\hline ADHERENCE/COMPLIANCE & FOLLOW-UP ASSESSMENT & OLLOWUP & $\mathrm{x}$ & $x$ & $\mathrm{x}$ & $x$ & $x$ & $\mathrm{x}$ & $\mathrm{x}$ & $x$ & & & & & & & & & & & & & & & & & & & & & & & & & & \\
\hline ADVERSE EVENTS & ADVERSE EVENTS & ADVERSE & $\mathrm{x}$ & & & $x$ & & $\mathrm{x}$ & $\mathrm{x}$ & $x \times$ & $x \times$ & $x \times$ & $\mathrm{x}$ & $x$ & $x$ & $x$ & $x$ & $x \times$ & $x \times$ & $x \times$ & $\mathrm{x}$ & $x$ & $x \times$ & r & $x$ & $x \times$ & $x \times$ & $x \times$ & $x \times$ & & $x \mathrm{x}$ & $x$ & $x$ & $\mathrm{x}$ & $\mathrm{x}$ & $\mathrm{x}$ \\
\hline ADVERSE EVENTS & ADVERSE EVENTS AND CONCOMITANT MEDICA & ICAECON & & $x$ & $\mathrm{x}$ & & & & & & & & & & & & & & & & & & & & & & & & & & & & & & & \\
\hline ADVERSE EVENTS & SERIOUS $A$ & SAE & $\mathrm{x}$ & $\mathrm{x}$ & $\mathrm{x}$ & $\mathrm{x}$ & $\mathrm{x}$ & $\mathrm{x}$ & $\mathrm{x}$ & & & & & & & & & & $\mathrm{x}$ & $\mathrm{x}$ & & & & $x$ & $x$ & & & & $\mathrm{x}$ & & $x$ & $\mathrm{x}$ & $x$ & $\mathrm{x}$ & $x$ & \\
\hline DRUG USE - BIOLOGIC & ALCOHOL BREATHALYZER & ALB & & & & & & & & & & & & $x$ & $x$ & $x$ & $x$ & $x \times$ & $x \times$ & $x$ & & $\mathrm{x}$ & & & & & $\mathrm{x}$ & & & & & & $\mathrm{x}$ & & & \\
\hline DRUG USE - BIOLOGIC & URINE DRUG SCREEN - AMPHET AMINES & UDS & & $x$ & $\mathrm{x}$ & $x$ & $\mathrm{x}$ & & $x$ & $x \times$ & & $x \times$ & & $x$ & $\mathrm{x}$ & $x$ & $x$ & $x \times$ & & $x$ & $\mathrm{x}$ & $\mathrm{x}$ & & & & & & & & & $x \times$ & & & $\mathrm{x}$ & $x$ & \\
\hline DRUG USE - BIOLOGIC & URINE DRUG SCREEN - COCAINE & UDS & & $\mathrm{x}$ & $\mathrm{x}$ & $\mathrm{x}$ & $\mathrm{x}$ & $x$ & $\mathrm{x}$ & $x \times$ & $x \quad x$ & $x \quad x$ & $\mathrm{x}$ & $\mathrm{x}$ & $x$ & $x$ & $\mathrm{x}$ & $x \quad x$ & & $x \quad x$ & $\mathrm{x}$ & $\mathrm{x}$ & $x \times$ & & & & $x \times$ & & & & $x \times$ & & $x$ & $\mathrm{x}$ & $x$ & $\mathrm{x}$ \\
\hline DRUG USE - BIOLOGIC & URINE DRUG SCREEN - OPIATES & UDS & & & $\mathrm{x}$ & $\mathrm{x}$ & $x$ & $\mathrm{x}$ & $x$ & $x \times$ & $x \times$ & $x$ & & $\mathrm{x}$ & $x$ & $x$ & $\mathrm{x}$ & $x \times$ & & & $\mathrm{x}$ & $\mathrm{x}$ & $x \times$ & & $x$ & & & & & & $x \times$ & $x$ & $x$ & $x$ & $x$ & $\mathrm{x}$ \\
\hline DRUG USE - BIOLOGIC & URINE DRUG SCREEN - OXYCODONE & UDS & & & & & & & & & & $\mathrm{x}$ & & & & & & & & & & & & & & & & & & & $x \times$ & & & & & \\
\hline DRUG USE - SELF REPORT/SU & IEADDICTION SEVERITY INDEX LITE & ASI & & & $x$ & $x$ & $\mathrm{x}$ & & $\mathrm{x}$ & $\mathrm{x}$ & $x \times$ & $x \quad x$ & $\mathrm{x}$ & $x$ & $x$ & $x$ & $x$ & $x$ & $\mathrm{x}$ & $x \times$ & $x$ & & $x$ & & $x$ & $x \times$ & & $x$ & & & $x \times$ & $x$ & $x$ & $\mathrm{x}$ & $x$ & $x$ \\
\hline DRUG USE - SELF REPORT/SL & IEADJECTIVE RATING SCALE FOR WITHDRAWAL & ARSW & & & & & & & & & $x \times$ & $x \quad x$ & & & & & & & & & & & & & & & & & & & & & & & & \\
\hline DRUG USE - SELF REPORT/SL & IEASI LITE DRUG/ & su & & & & & & & & & $x \times$ & $x \quad x$ & $\mathrm{x}$ & $x$ & $x$ & $x$ & $x$ & $x \times$ & $x \times$ & $x \quad x$ & $x$ & & $x$ & & & & & & & & & $\mathrm{x}$ & $x$ & & & \\
\hline DRUG USE - SELF REPORT/SU & IESUBSTANCE US: & SUR & $x$ & & $x$ & & $x$ & & $x$ & $x$ & & & & & & & & $x$ & & & & & & $x$ & $x$ & & & & & & & & & & & $x$ \\
\hline DRUG USE - SELF REP & IESUBST & CALENDAF & & & & & & & & & & & & $\mathrm{x}$ & $x$ & & & & $\mathrm{x}$ & $x$ & & & & & $x$ & $x$ & & & & & & & & ( & . & \\
\hline ENROLLMENT/RANDOMIZAT & V/EXCLUSION CRITERIA & INCEXC & & & $\mathrm{x}$ & $x$ & $x$ & $x$ & & 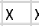 & $x>1$ & $x \quad x$ & & $\mathrm{x}$ & $x$ & $x$ & $x$ & $x \quad x$ & $x \quad x$ & $x \quad x$ & $x$ & & $x \quad x$ & $x$ & $x$ & $x \quad x$ & $x \times$ & $x$ & $x$ & & $x \times$ & $x$ & $x$ & $x$ & $x$ & $x$ \\
\hline HEALTH - GENERAL/PHYS & L ELECTROC & ECG & $x$ & $x$ & $\mathrm{x}$ & $x$ & $x$ & $x$ & $x$ & $x$ & & & & & & & & $x$ & & & & & $\mathrm{x}$ & & & & & $x$ & $x$ & & & $\mathrm{x}$ & $x$ & $\mathrm{x}$ & $x$ & $x$ \\
\hline HEALTH - GENERAL/PHYSICA & L HEMATOLOGY & HEMAT & $x$ & $x$ & $x$ & $x$ & & $x$ & $x$ & $x$ & & & & & & & & $x$ & $x$ & & & & & & & & & & & & & $\mathrm{x}$ & $x$ & $x$ & $x$ & \\
\hline HEALTH - GEI & ASE ASSESSMENT & INFEC & $\mathrm{x}$ & $x$ & $\mathrm{x}$ & $x$ & $x$ & & $x$ & $x$ & & & & & & & & & & & & & & & & & & & & & $x$ & $\mathrm{x}$ & $x$ & $x$ & $x$ & $x$ \\
\hline HEALTH - GENERAL/PHYSICA & L MEDICAL HISTORY & MEDHIST & $x$ & $x$ & $x$ & $\mathrm{x}$ & $x$ & $\mathrm{x}$ & $\mathrm{x}$ & $x \times y$ & $x$ & $x \quad x$ & & & & & & $x$ & & & & & $\mathrm{x}$ & $6 x$ & $x$ & $x$ & & $x$ & $x$ & & $x \times$ & $x$ & $x$ & $\mathrm{x}$ & $x$ & $x$ \\
\hline HEALTH - MENTAL/BE & R.BECK & & & & & & & & & & & & & & & & & x & & & & & $\mathrm{x}$ & i & & & & & & & & & & & & \\
\hline HEALTH - MENTAL/BEHAVIO & R. HAMILTON DEPRESSION RATING SCA & AMD & & & $x$ & & $x$ & $x$ & & $x$ & & & & & & & & & & & & & & & & & & & & & $x$ & $\mathrm{x}$ & $x$ & $x$ & $x$ & $x$ \\
\hline $\mathrm{HE}$ & R. HIV & 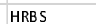 & & & & & $x$ & & $\mathrm{x}$ & $x$ & $x$ & $x$ & & $\mathrm{x}$ & $x$ & $\mathrm{x}$ & $x$ & & & & & & $x$ & & & & & & & & & $\mathrm{x}$ & $x$ & $\mathrm{x}$ & $x$ & $x$ \\
\hline HEALTH - MENTAL/BEHAVIO & R.S SAD WORKSHEET & SaD & & & $x$ & $x$ & $x$ & $x$ & $x$ & $x$ & & & & & & & & & $\mathrm{x}$ & & & & $\mathrm{x}$ & & & & & $x$ & $x$ & & & & $x$ & $\mathrm{x}$ & $x$ & \\
\hline
\end{tabular}


Figure 4. Excerpt from Assessment Schedule Table

Cont. Table 2: Study schema of RCTs on stimulant use disorder and the assessment points by instruments

\begin{tabular}{|c|c|c|c|c|c|c|c|c|c|c|c|c|c|c|c|c|c|c|c|c|c|c|c|c|c|c|c|c|c|c|}
\hline \multirow{2}{*}{$\begin{array}{l}\text { Study } \\
\text { ID }\end{array}$} & \multirow[b]{2}{*}{ Instrument } & \multicolumn{29}{|c|}{ Study week } \\
\hline & & 0 & 1 & 2 & 3 & 4 & 5 & 6 & 7 & 8 & 9 & 10 & 11 & 12 & 13 & 14 & 15 & 16 & 17 & 18 & 19 & 20 & 21 & 22 & 23 & 24 & 28 & $\begin{array}{c}36 \\
(9 \mathrm{~m})\end{array}$ & 48 & $\begin{array}{c}52 \\
(12 \mathrm{~m})\end{array}$ \\
\hline \multirow{4}{*}{$\begin{array}{l}\text { 怘 } \\
\text { 足 }\end{array}$} & Phase & B & \multicolumn{12}{|c|}{ A } & \multicolumn{4}{|c|}{$F$} & & & & & & & & & & & & \\
\hline & ASI & $\sqrt{ }$ & & & & & & & & & & & & $\sqrt{ }$ & & & & & & & & & & & & & & & & \\
\hline & UDS $^{*}$ & $3 \sqrt{ }$ & $3 \sqrt{ }$ & $3 \sqrt{ }$ & $3 \sqrt{ }$ & $3 \sqrt{ }$ & $3 \sqrt{ }$ & $3 \sqrt{ }$ & $3 \sqrt{ }$ & $3 \sqrt{ }$ & $3 \sqrt{ }$ & $3 \sqrt{ }$ & $3 \sqrt{ }$ & $3 \sqrt{ }$ & & & & $\sqrt{ }$ & & & & & & & & & & & & \\
\hline & $\overline{R B M}$ & $\sqrt{ }$ & & & & & & & & & & & & $\sqrt{ }$ & & & & $\sqrt{ }$ & & & & & & & & & & & & \\
\hline \multirow{4}{*}{ 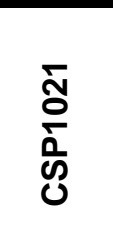 } & Phase & B & \multicolumn{8}{|c|}{ A } & \multicolumn{4}{|c|}{$F$} & & & & & & & & & & & & & & & & \\
\hline & ASI & $\sqrt{ }$ & & & & $\sqrt{ }$ & & & & $\sqrt{ }$ & & & & & & & & & & & & & & & & & & & & \\
\hline & UDS $^{*}$ & $3 \sqrt{ }$ & $3 \sqrt{ }$ & $3 \sqrt{ }$ & $3 \sqrt{ }$ & $3 \sqrt{ }$ & $3 \sqrt{ }$ & $3 \sqrt{ }$ & $3 \sqrt{ }$ & $3 \sqrt{ }$ & & $\sqrt{ }$ & & $\sqrt{ }$ & & & & & & & & & & & & & & & & \\
\hline & $\overline{R B M}$ & $\sqrt{ }$ & & & & & & & & $\sqrt{ }$ & & & & & & & & & & & & & & & & & & & & \\
\hline \multirow{4}{*}{$\begin{array}{l}\text { స्. } \\
\text { ơ } \\
\text { ஸे }\end{array}$} & Phase & B & \multicolumn{13}{|c|}{ A } & \multicolumn{4}{|c|}{$\mathrm{F}$} & & & & & & & & & & & \\
\hline & $\overline{A S I}$ & $\sqrt{ }$ & & & & $\sqrt{ }$ & & & & $\sqrt{ }$ & & & & $\sqrt{ }$ & & & & & $\sqrt{ }$ & & & & & & & & & & & \\
\hline & UDS & $3 \sqrt{ }$ & $3 \sqrt{ }$ & $3 \sqrt{ }$ & $3 \sqrt{ }$ & $3 \sqrt{ }$ & $3 \sqrt{ }$ & $3 \sqrt{ }$ & $3 \sqrt{ }$ & $3 \sqrt{ }$ & $3 \sqrt{ }$ & $3 \sqrt{ }$ & $3 \sqrt{ }$ & $3 \sqrt{ }$ & & & & & $\sqrt{ }$ & & & & & & & & & & & \\
\hline & RBM & $\sqrt{ }$ & & & & & & & & & & & & $\sqrt{ }$ & & & & & $\sqrt{ }$ & & & & & & & & & & & \\
\hline \multirow{4}{*}{ 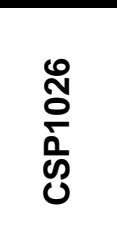 } & Phase & B & \multicolumn{12}{|c|}{ A } & \multicolumn{4}{|c|}{$\bar{F}$} & & & & & & & & & & & & \\
\hline & ASI & $\sqrt{ }$ & & & & & & $\sqrt{ }$ & & & & & & $\sqrt{ }$ & & & & & & & & & & & & & & & & \\
\hline & UDS $^{\star \star}$ & $3 \sqrt{ }$ & $3 \sqrt{ }$ & $3 \sqrt{ }$ & $3 \sqrt{ }$ & $3 \sqrt{ }$ & $3 \sqrt{ }$ & $3 \sqrt{ }$ & $3 \sqrt{ }$ & $3 \sqrt{ }$ & $3 \sqrt{ }$ & $3 \sqrt{ }$ & $3 \sqrt{ }$ & $3 \sqrt{ }$ & & & & $\sqrt{ }$ & & & & & & & & & & & & \\
\hline & $\overline{R B M}$ & $\sqrt{ }$ & & & & & & & & & & & & $\sqrt{ }$ & & & & & & & & & & & & & & & & \\
\hline \multirow{4}{*}{$\frac{\sqrt[m]{m}}{\frac{m}{6}}$} & Phase & B & \multicolumn{8}{|c|}{ A } & \multicolumn{16}{|c|}{$\mathrm{F}$} & & & & \\
\hline & ASI & $\sqrt{ }$ & & & & & & & & & & & & $\sqrt{ }$ & & & & & & & & & & & & $\sqrt{ }$ & & & & \\
\hline & UDS & $\sqrt{ }$ & & & & $\sqrt{ }$ & & & & $\sqrt{ }$ & & & & $\sqrt{ }$ & & & & & & & & & & & & $\sqrt{ }$ & & & & \\
\hline & RBM & & & & & & & & & & & & & & & & & & & & & & & & & & & & & \\
\hline
\end{tabular}

B: Baseline/Screening phase; A: Active treatment phase; F: Follow-up phase; ASI: Addiction Severity Index; UDS: Urine Drug Screening; RBM: Risk Behavior Measures

${ }^{*}$ Three times a week for benzoylecgonine (BE) and creatinine and once a week for the other drugs

** Three times a week for Methamphetamine and creatinine. Other drugs were examined only at baseline. 


\begin{tabular}{|c|c|c|}
\hline $\begin{array}{l}\text { NIDA study } \\
\text { code }\end{array}$ & Study title & $\mathbf{N}$ \\
\hline CSP999 & A multicenter clinical trial of buprenorphine in treatment of opiate dependence & 736 \\
\hline CSP1008A & A multicenter efficacy/safety trial of buprenorphine/naloxone for the treatment of opiate dependence & 326 \\
\hline CSP1019 & Double-blind, placebo-controlled trial of selegiline transdermal system for the treatment of cocaine dependence & 300 \\
\hline CSP1020 & A phase III placebo-controlled, double-blind multi-site trial of lofexidine for opiate withdrawal & 68 \\
\hline CSP1021 & Double-blind, placebo-controlled multi-center trial of baclofen for the treatment of cocaine dependence & 160 \\
\hline CSP1022 & Phase 2, double-blind, placebo-controlled trial of selegiline transdermal system (STS) as an aid for smoking cessation & 246 \\
\hline CSP1025 & Phase 2, double-blind, placebo-controlled trial of topiramate for the treatment of methamphetamine dependence & 140 \\
\hline CSP1026 & Phase 2, double-blind, placebo-controlled trial of modafinil for methamphetamine dependence & 210 \\
\hline CTN0001 & Buprenorphine/naloxone versus clonidine for inpatient opiate detoxification & 113 \\
\hline CTN0002 & Buprenorphine/naloxone versus clonidine for outpatient opiate detoxification & 230 \\
\hline CTN0003 & Suboxone (buprenorphine/naloxone) taper: a comparison of two schedules & 516 \\
\hline CTN0004 & Motivational enhancement therapy (met) to improve treatment engagement and outcome in subjects seeking treatment for substance abuse & 461 \\
\hline CTN0005 & $\mathrm{Ml}$ (motivational interviewing) to improve treatment engagement and outcome in subjects seeking treatment for substance abuse & 423 \\
\hline CTN0006 & Motivational incentives for enhanced drug abuse recovery: drug free clinics & 454 \\
\hline CTN0007 & Motivational incentives for enhanced drug abuse recovery: methadone clinics & 403 \\
\hline CTN0009 & Smoking cessation treatment with transdermal nicotine replacement therapy in substance abuse rehabilitation program & 225 \\
\hline CTN0010 & Buprenorphine/naloxone-facilitated rehabilitation for opioid dependent adolescents/young adults & 154 \\
\hline CTN0013 & Motivational enhancement therapy (MET) to improve treatment utilization and outcome in pregnant substance users & 200 \\
\hline CTN0014 & Brief strategic family therapy (BSFT) for adolescent drug abusers & 482 \\
\hline CTN0015 & Women's treatment for trauma and substance use disorders & 353 \\
\hline CTN0021 & MET to improve treatment engagement and outcome for Spanish-speaking individuals seeking treatment for substance abuse & 436 \\
\hline CTN0029 & A pilot study of osmotic-release methylphenidate in initiating and maintaining abstinence smokers with ADHD & 225 \\
\hline CTN0030 & A two-phase randomized controlled clinical trial of buprenorphine/naloxone treatment plus individual drug counseling for opioid analgesic dependence & 665 \\
\hline CTN0030A3 & $\begin{array}{l}\text { Long-term follow-up to ctn-0030 (a two-phase RCTs of buprenorphine/naloxone treatment plus individual drug counseling for opioid analgesic } \\
\text { dependence) }\end{array}$ & 375 \\
\hline CTN0031 & $\begin{array}{l}\text { Stimulant abuser groups to engage in 12-step: evaluation of a combined individual-group intervention to reduce stimulant and other drug use by increasing } \\
12 \text {-step involvement }\end{array}$ & 471 \\
\hline CTN0037 & Stimulant reduction intervention using dosed exercise (stride) & 302 \\
\hline CTN0044 & Web-delivery of evidence-based, psychosocial treatment for substance $u$ & 507 \\
\hline CTN0046 & $\begin{array}{l}\text { Smoking-cessation and stimulant treatment (s-cast): evaluation of the impact of concurrent outpatient smoking-cessation and stimulant treatment on } \\
\text { stimulant-dependence outcomes }\end{array}$ & 538 \\
\hline CTN0047 & Screening, assessment, referral, and treatment in emergency departments (SMART-ED) & 1285 \\
\hline CTN0048 & Cocaine use reduction with buprenorphine (curb) & 302 \\
\hline CTN0051 & Extended-release naltrexone vs. Buprenorphine for opioid treatment & 570 \\
\hline CTN0052 & A randomized controlled evaluation of buspirone for relapse-prevention in adults with cocaine dependence (BRAC) & 62 \\
\hline СT00001 & Phase 2, double-blind, placebo-controlled trial of reserpine for the treatment of cocaine dependence & 119 \\
\hline СТ00005 & Double-blind, placebo-controlled trial of ondansetron for the treatment of cocaine dependence & 65 \\
\hline СТ00007 & Phase 2, double-blind, placebo-controlled trial of cabergoline for the treatment of cocaine dependence & 140 \\
\hline MDS0004 & Phase 2, double-blind, placebo-controlled trial of modafinil for the treatment of cocaine dependence & 210 \\
\hline MDS0007 & Phase 2, double-blind, placebo-controlled trial of bupropion for methamphetamine dependence & 205 \\
\hline
\end{tabular}


Table 2. Socio-demographic characteristics of the harmonized data

\begin{tabular}{|c|c|c|c|c|c|c|c|c|c|}
\hline \multirow[t]{2}{*}{ Study ID } & \multicolumn{4}{|c|}{ Arms } & \multirow[t]{2}{*}{ Sample size, $\mathbf{n}$} & \multirow[t]{2}{*}{ Female, \% } & \multirow[t]{2}{*}{ Age, mean } & \multirow[t]{2}{*}{ White, \% } & \multirow[t]{2}{*}{ Married, \% } \\
\hline & Treatment 1 & Treatment 2 & Treatment 3 & Treatment4/ placebo & & & & & \\
\hline CSP999 & Bup(1 mg) & Bup(4 mg) & Bup(8 mg) & Bup(16 mg) & 736 & 32.5 & 36.0 & 48.8 & 26.4 \\
\hline CSP1008A & Bup-Nx & $\mathrm{BU}$ & - & Placebo & 326 & 35.0 & 37.6 & 60.4 & 22.2 \\
\hline CSP1019 & Selegiline & - & - & Placebo & 300 & 22.0 & 40.7 & 26.5 & 18.7 \\
\hline CSP1020 & Lofexidine & - & - & Placebo & 68 & 13.2 & 41.3 & 51.5 & 17.6 \\
\hline CSP1021 & Baclofen & - & - & Placebo & 160 & 20.6 & 42.7 & 25.6 & 20.6 \\
\hline CSP1022 & Selegiline & - & - & Placebo & 246 & 49.2 & 46.5 & 68.7 & 43.5 \\
\hline CSP1025 & Topiramate & - & - & Placebo & 140 & 36.4 & 38.0 & 77.9 & 18.6 \\
\hline CSP1026 & Modafinil 200 & Modafinil 400 & - & Placebo & 210 & 40.9 & 39.0 & 73.3 & 21.9 \\
\hline CTN0001 & Bup-Nx & Clonidine & - & - & 113 & 39.8 & 36.2 & 55.7 & 23.0 \\
\hline CTN0002 & Bup-Nx & Clonidine & - & - & 230 & 28.3 & 38.8 & 40.0 & 15.7 \\
\hline CTN0003 & Bup-Nx(7-d taper) & Bup-Nx(28-d taper) & - & - & 516 & 33.0 & 35.9 & 76.5 & 24.2 \\
\hline CTN0004 & MET & - & - & ST & 461 & 29.1 & 35.3 & 42.0 & 15.6 \\
\hline CTN0005 & $\mathrm{Ml}$ & - & - & ST & 423 & 42.1 & 33.3 & 71.9 & 17.0 \\
\hline CTN0006 & Incentives & - & - & TAU & 454 & 54.9 & 35.9 & 35.7 & 18.5 \\
\hline CTN0007 & Incentives & - & - & TAU & 403 & 43.9 & 41.9 & 25.6 & 10.9 \\
\hline CTN0009 & $\mathrm{SmC}$ & - & - & TAU & 225 & 48.0 & 42.1 & 36.0 & 18.7 \\
\hline CTN0010 & Bup-Nx(12-week) & Bup-Nx(14-day) & - & - & 154 & 41.6 & 19.7 & 70.1 & 5.2 \\
\hline CTN0013 & MET & - & - & ST & 200 & 100.0 & 26.2 & 37.2 & 14.5 \\
\hline CTN0014 & BFST & - & - & TAU & 482 & 21.4 & 16.0 & 40.8 & - \\
\hline CTN0015 & SS & WHE & - & - & 353 & 100.0 & 39.2 & 48.9 & 15.9 \\
\hline CTN0021 & MET & - & - & CAU & 436 & 10.8 & 32.7 & 0.0 & 29.4 \\
\hline CTN0029 & ORMeth & - & - & Placebo & 255 & 43.5 & 37.8 & 80.4 & - \\
\hline CTN0030 & Bup-Nx+SC & Bup-x+EIC & - & - & 665 & 39.6 & 33.2 & 90.8 & 28.6 \\
\hline CTN0031 & STAGE-12 & - & - & TAU & 471 & 58.8 & 38.3 & 50.3 & 12.5 \\
\hline CTN0037 & Exercise & Health Education & - & - & 302 & 40.1 & 38.5 & 45.4 & 13.2 \\
\hline CTN0044 & TES & - & - & TAU & 507 & 37.9 & 35.4 & 57.6 & 14.2 \\
\hline CTN0046 & $\mathrm{TAU}+\mathrm{SmC}$ & - & - & TAU & 538 & 48.0 & 37.0 & 59.5 & 10.8 \\
\hline CTN0047 & $\mathrm{BS}+\mathrm{B}$ & SAR & MS & - & 1285 & 30.1 & 36.4 & 38.0 & 9.5 \\
\hline CTN0051 & Nalt-ER & Bup-Nx & - & - & 570 & 33.9 & 33.9 & 69.1 & 9.1 \\
\hline CTN0052 & Buspirone & - & - & Placebo & 62 & 37.1 & 46.1 & 25.8 & 12.9 \\
\hline CTO0001 & Reserpine & - & - & Placebo & 119 & 29.4 & 41.0 & 21.0 & 17.8 \\
\hline CTO0005 & Ondansetron $0.25 \mathrm{mg}$ & Ondansetron $1 \mathrm{mg}$ & Ondansetron $4 \mathrm{mg}$ & Placebo & 65 & 15.4 & 36.2 & 38.5 & 20.0 \\
\hline CTO0007 & Cabergoline & - & - & Placebo & 140 & 15.0 & 40.1 & 37.9 & 25.0 \\
\hline MDS0004 & Modafinil 200 & Modafinil 400 & - & Placebo & 210 & 28.1 & 41.8 & 39.2 & 18.6 \\
\hline MDS0007 & Bupropion & - & - & Placebo & 205 & 35.1 & 39.3 & 68.3 & 15.6 \\
\hline
\end{tabular}

Abbreviations: Bup: Buprenorphine; Bup-Nx: Buprenorphine-Naloxone; BS+B: Brief Intervention plus Booster; BSFT: Brief Strategic Family Therapy; CAU: Counseling as usual; EIC:

Enhanced Individual Counseling; Hisp: Hispanic; HS: High School; MET: Motivational Enhancement Therapy; MI: Motivational Interviewing; MS: Minimal Screening; NA: Not-applicable; Nalt-

ER: Naltrexone-ER; NH black: Non-Hispanic black; NH white: Non-Hispanic white; ORMeth: Osmotic-Release Methylphenidate; SAR: Screening, Assessment, and Referral; SC: Standard

Counseling; SmC: Smoking cessation; ST: Standard treatment; SS: Seeking Safety; TAU: Treatment as usual TES: Therapeutic Education System; WHE: Women's Health Education 